\title{
Rapor
}

\section{D vitamini ve Tip 2 diyabet}

\author{
Arda Karagöla, Nazlı Atakb \\ a Dr., Ankara Üniversitesi Tıp Fakültesi, Halk Sağlığı AD., Ankara \\ b Prof. Dr., Ankara Üniversitesi Tıp Fakültesi, Halk Sağlığı AD., Ankara
}

Geliş tarihi: 26.02.2016, Kabul tarihi: 28.11.2016

\section{Özet}

$\mathrm{Bu}$ çalışmanın amacı, tip 2 diyabet ile $\mathrm{D}$ vitamini yetersizliği arasındaki olası ilișkinin değerlendirilmesidir. Tip 2 diyabet (T2D) morbidite ve mortalitesi giderek artmaktadır. T2D ve komplikasyonlarının tedavisinde ilerleme kaydedilmesine rağmen, hastalık yükünün giderek artması, korunmada yeni yaklaşımların gerekliliğini ortaya koymaktadır. Ekolojik kanıtlar, D vitamini yetersizliğinin belirgin olduğu az güneş alan bölgelerde, diyabet sıklığının arttığını göstermiștir. D vitamini son zamanlarda T2D'in etiyopatogenezi ve önlenmesinde giderek artan bir şekilde gündeme gelmektedir. Yetersizliğinin T2D riskini arttırdığı belirtilmekle birlikte, nedensel ilișki ile ilgili kanıtlar, yeterli sayıda yüksek kalitede randomize kontrollü çalışmalar bulunmadığı için sınırlıdır. Korunmada yașam biçimi ve davranışlarının değiștirilmesi yüksek riskli bireylerde önemli bir yaklaşımdır. Ek olarak 25(OH)D3 düzeyinin arttırılması da, T2D'in önlenmesi ve tedavisinde umut vadeden bir yaklaşım olabilir. Bu konuda bazı önemli sonuçlara ulaşılmış olsa da ileriye dönük geniş kapsamlı çalışmalara gereksinim bulunmaktadır.

Anahtar kelimeler: D vitamini, Tip 2 diyabet, D vitamini eksikliği, D vitamini yetersizliği, korunma

\section{Vitamin D and Type 2 Diabetes}

\begin{abstract}
This report discussed the potential association between vitamin D deficiency and type 2 diabetes. The morbidity and the mortality of type 2 diabetes (T2D) is increasing. Although some progress has been achieved in the treatment of its complications, the increase in the burden of
\end{abstract}

Sorumlu Yazar: Nazlı Atak, Ankara Üniversitesi Tıp Fakültesi, Halk Sağlığı AD., Ankara.

Tel: 03123638990 / 8601, E-mail: nazliatak64@yahoo.com 
the disease, leads to the requirement of new approaches in prevention. The ecological evidence has shown that the prevalence of T2D has increased in the sunny places where vitamin D deficiency is prominent. Recently, vitamin D has increasingly come onto the agenda in the etiopathogenesis and the prevention of T2D. Although it has been shown that vitamin D deficiency increases the risk of T2D, the body of evidence is not sufficient to demonstrate a cause- effect relationship since high quality randomised controlled trials are lacking. The change in life style and behaviors of the high-risk individuals are important. Additionally, it may prove to be a promising approach in the prevention and treatment of T2D to increase the level of 25(OH)D3. Although some remarkable outcomes have been reported, future large-scale investigations are still needed.

Keywords: Vitamin D, Type 2 diabetes, Vitamin D insufficiency, Vitamin D deficiency, prevention

\section{Giriş}

D vitamini, insülin salınımı ve faaliyeti üzerindeki etkisi nedeniyle glikoz metabolizmasını düzenlemektedir. Ekolojik kanitlar, D vitamini yetersizliğinin belirgin olduğu az güneş alan bölgelerde, diyabet ve hipertansiyon gibi metabolik hastalıkların sıklığının arttığını göstermiştir. Çok yakın zamanda yapılan yeni çalışmalara göre, değişen $\mathrm{D}$ vitamini ve kalsiyum dengesinin, tip 2 diyabetin (T2D) gelişiminde etkili olduğu düşünülmektedir. ${ }^{1}$

\section{D vitamini fizyolojisi:}

$\begin{array}{ccc}\text { D vitamini, çok işlevli bir hormon } \\ \text { olup, }^{2-4} & \text { bağışılklı } & \text { sisteminin }\end{array}$ regülasyonundan iyon metabolizmasına kadar birçok temel fonksiyonu etkilemektedir. Asıl görevi, iskelet sisteminde kalsiyum ve fosfat dengesini düzenlemesi ve kemik mineralizasyonu olup, iskelet dişı görevleri de bulunmaktadır. ${ }^{5-7}$ Vitaminin insandaki temel kaynağının güneş ışınlarına maruziyet olduğu bilinmektedir. Yağda çözünmekte ve yağ dokusunda depolanmaktadır.8,9 Günlük D vitamini ihtiyacının ancak \%30'u besinlerle, geri kalanı da epidermiste bulunan dehidrokolesterolün güneş ıșığıyla fotokimyasal tepkimeye girmesi sonucu karşılanmaktadır. ${ }^{8} \mathrm{Bu}$ endojen sentez sirasinda epidermiste bulunan dehidrokolesterol 7-dehidrokolesterole dönüşmekte; 7-dehidrokolesterol, karaciğerde 25-hidroksi vitamin $\mathrm{D}_{3}{ }^{\prime} \mathrm{e}$ $\left[25(\mathrm{OH}) \mathrm{D}_{3}\right]$; böbreklerde de vitaminin aktif formu olan 1,25-dihidroksi vitamin $\mathrm{D}_{3}{ }^{\prime} \mathrm{e}$ $\left[1,25(\mathrm{OH})_{2} \mathrm{D}_{3}\right]$ dönüşmektedir. ${ }^{8-10}$ Serumda bulunan $25(\mathrm{OH}) \mathrm{D}_{3}, \quad \mathrm{D}$ vitamini reseptörlerine bağlanarak ince bağırsaklardan kalsiyum ve fosforun; böbreklerden de kalsiyumun geri emilimini arttırarak plazma mineral dengesini ve kemik gelişimini düzenlemektedir. ${ }^{8} \mathrm{Bu}$ mekanizmanın işlemesi, paratiroid bezlerini doğrudan inhibe ederek parathormon düzeyini azaltmakta ve serum kalsiyum miktarının artmasını sağlamaktadır. ${ }^{11}$ Kolekalsiferol, öncelikle yağ dokusunda depolandığından, vücut yağ oranının artması, kolekalsiferolün biyoyararlılığını azaltmaktadır. ${ }^{5}$ Aktif metabolit $1,25(\mathrm{OH})_{2} \mathrm{D}_{3}$ olmasına rağmen, serum $\mathrm{D}$ vitamini düzeyi, alım ve endojen üretim; yarılanma ömrü uzun olan ve depo $\mathrm{D}$ vitamini düzeyini yansitan ${ }^{5}$ serum 25 hidroksi $\mathrm{D}_{3}\left[25(\mathrm{OH}) \mathrm{D}_{3}\right]$ düzeyi ile değerlendirilmektedir. ${ }^{8-10}$

Tablo 1'de serum 25(OH) $\mathrm{D}_{3}$ değerlerine göre $\mathrm{D}$ vitamini durumu verilmektedir. ${ }^{12}$

D vitamini yetersizliği ve eksikliği için kesme noktası $20 \mathrm{ng} / \mathrm{mL}$ olup, ${ }^{13} 50$ $\mathrm{ng} / \mathrm{mL}$ ve üzeri yeterli kabul edilmektedir. ${ }^{14}$ 
Tablo 1. Serum $25(\mathrm{OH}) \mathrm{D}_{3}$ düzeyine göre $\mathrm{D}$ vitamini durumu

\begin{tabular}{ccc}
\hline Serum 25(OH) $\mathbf{D}_{3}$ Değerleri & \\
\cline { 1 - 1 } $\mathbf{n g} / \mathbf{m L}$ & $\mathbf{n m o l} / \mathbf{L}$ & D Vitamini Durumu \\
\hline$<12$ & $<30$ & D vitamini eksikliği (deficiency) \\
$12-20$ & $30-50$ & D vitamini yetersizliği (insufficiency) \\
$\geq 20$ & $\geq 50$ & Yeterli D vitamini düzeyi \\
$>50$ & $>125$ & Potansiyel olumsuz etkiler \\
\hline
\end{tabular}

Tip 2 diyabet gelişiminde D vitaminin rolü:

T2D ve D vitamini ilişkisi, ilk kez Gedik ve Akalın tarafından 1986 yılında D vitamini eksikliği olan görece dört sağlıklı kişide, insülin salınımının bozulması ve 6 ay süre ile $\mathrm{D}$ vitamini verildikten sonra insülin salınımının normale döndügünün belirlenmesi ile gündeme gelmiştir. ${ }^{15}$

D vitamini ile T2D arasındaki fizyolojik ilişki detaylı bir şekilde incelenmiştir. Yetersizliği, glukagon salınımını değiştirmeden elektrik bağımlı seçici olmayan $\mathrm{Ca}^{2+}$ kanalları üzerinden hücre içi $\mathrm{Ca}^{2+}$ konsantrasyonunu artırarak insülin salınımını azaltmaktadır. 8,14

D vitamini reseptörleri; beta hücrelerinde ve periferde, insüline cevap veren iskelet kası ile yağ dokusu gibi hedef dokularda ve çeşitli hücrelerde bulunmaktadır.12,16-18 D vitamini, beta hücrelerinde bulunan reseptörleri uyararak insülinin salınmasını ve pankreasta bulunan D vitamin bağımlı kalsiyum bağlayan proteinlerin aktifleşmesini sağlamaktadır.8,19 Yapılan in vitro ve in vivo çalışmalar, D vitamininin glikoza cevap olarak glikoz toleransının sürdürülmesi için gerekli olan normal insülin salınımından sorumlu olduğunu göstermiştir. ${ }^{8}$

düzeyinin

Bazı çalışmalarda, düşük D vitamini komplikasyonlardan çok, makrovasküler komplikasyonlara neden olduğu belirtilmiștir. $^{19}$

T2D; insülin direnci ve beta hücre disfonksiyonu gibi iki temel metabolik eksiklik sonucu ortaya çlkmaktadır. ${ }^{13}$ Hayvan çalışmaları vitaminin, insülin duyarlılığı ve salınımı ile glikoz toleransının sürdürülmesinde önemli rol oynadığını göstermektedir: ${ }^{10}$

a) Insülin direnci: D vitamini reseptörleri, yağ dokusu ve iskelet kasında bulunmakta olup, periferik insülin duyarlılığının belirlenmesinde rol oynamaktadır. ${ }^{12} \mathrm{D}$ vitamini insülinin işlevini, insülin reseptörünün ifadesini güçlendirerek ya doğrudan ya da hücre içi ve hücre dişı kalsiyum akışını değiştirerek dolaylı etkilemektedir. ${ }^{16}$ Kalsiyum, insülinle tepkimeye giren iskelet kası ve yağ dokusu gibi insüline cevap veren dokularda, hücre içi süreçlerde etkili olup, $\mathrm{Ca}^{+2}$ un oldukça dar bir aralıkta değişmesi, insülinin optimal düzeyde işlev görmesini sağlamaktadır. $\mathrm{Bu}$ nedenle temel olarak insülinin hedef dokularındaki hücre içi $\mathrm{Ca}^{+2}$ un değişmesi, periferik insülin direncine yol açarak insülin sinyalizasyonunu bozmakta ve glikozu hücre içine taşıyan Glut-4 aktivitesinin azalmasına yol açabilmektedir. ${ }^{20-22}$

D vitamini yetersizliğinde, kalsiyum emilimi azaldığı için, sekonder olarak 
parathormon salgilanmakta; böbreklerden kalsiyum geri emilimi artmaktadır. $\mathrm{Bu}$ durum, hücre içi kalsiyum düzeyini arttırarak insülinin hedef hücrelerde işlev görmesi için gerekli olan hücre içi kalsiyum akışının algılamasını inhibe etmekte ve insülin duyarlılığını azaltmaktadır. ${ }^{12}$ İnsülin duyarlılığının azalması, paratiroid hormon salınımını arttırmaktadır. ${ }^{10}$ D vitamini yetersizliği, paratiroid hormon salgılanmasına neden olarak hücre içi kalsiyum artışına yol açmaktadır. Uzamış hücre içi kalsiyum yüksekliği, insülinin hedef hücrelerde etkimesi için gerekli olan hücre içi kalsiyum akıșını algılanmasını inhibe etmektedir. ${ }^{10} \mathrm{Bu}$ șekilde düșük $\mathrm{D}$ vitamini düzeyinin bir sonucu olarak artan parathormon, beta hücrelerinden insülin salınımını olumsuz etkilemektedir. ${ }^{19}$

b) Beta hücre disfonksiyonu: D vitamini, bazal insülin salınımını etkilememekle birlikte, glikoz artışına cevap olarak salınan insülin düzeyini etkilemektedir.16 D vitamininin dolaşımdaki aktif formu olan $1,25(\mathrm{OH})_{2} \mathrm{D}_{3}$; beta hücrelerindeki D vitamini reseptörlerine bağlanarak hücre dişı ve hücre içi kalsiyum akışını düzenlemektedir. İnsülin salınımı, kalsiyum bağımlı bir süreç olup, kalsiyum akışındaki değişiklikler, beta hücrelerinin insülin salgılamasını olumsuz yönde etkileyebilmektedir. ${ }^{16}$ Buradaki temel mekanizma; D vitamini eksikliği veya yetersiz kalsiyum alımının, beta hücresindeki hücre dışı ve hücre içi kalsiyum havuzları arasındaki dengeyi bozması ve glikoza cevap olarak oluşan insülin salınımını kesintiye uğratmasıdır.12,16 Beta hücrelerinden insülin salınması, akut hücre içi kalsiyum artışına bağlı olarak gerçekleşmektedir.10

\section{Vitamini yetersizliği ve Tip 2 Diyabet:}

D vitamini yetersizliği, son dönemde dünyada önemli bir konu olarak gündeme gelmiş ${ }^{9}$ ve pandemi olarak tanımlanmıştır. ${ }^{23}$ Yaklaşık 1 milyar kişide D vitamini yetersizliği olduğu bildirilmektedir. ${ }^{17}$ Son 10 yllda D vitaminin işlevlerine ilişkin yeni çalışmalar yapılmış olup, iskeletle ilişkili işlevinin yanı sıra yetersizliğinin kanser, romatoid artrit ve multipl skleroz gibi otoimmun bozukluklar, hipertansiyon, metabolik sendrom, kardiyovasküler hastalıklar, tip 1 ve tip 2 diyabetle ilişkili olduğu gösterilmiștir. ${ }^{\text {-57, } 12,13,16,19,24}$

T2D; insülin sekresyonu, duyarlılığı veya her ikisinin defekti sonucu ortaya çıkmaktadır. ${ }^{25}$ Morbidite ve mortalitesi giderek artmaktadır.13,16,26,27 Tüm diyabet olgularının \%90-95'ini olușturmaktadır. ${ }^{28}$ Dünya Sağlık Örgütü (DSÖ)'ne göre, 18 yaş ve üzerinde diyabet prevalansı $\% 8.5$ olup, 1980 yılına göre 2 kat artmıștır. ${ }^{26} 2012$ yılında kronik hastalıklara bağlı 38 milyon ölüm görülmüş olup, bu ölümlerin $\% 4$ 'ü diyabet nedeniyle meydana gelmiștir. Diyabet prevalansının en yüksek olduğu bölge Doğu Akdeniz iken, en düşük olduğu bölge Avrupa ve Batı Pasifik'tir (sırasıyla $\% 8$ ve $\% 9)^{27}$

Satman ve arkadaşlarının 2010 yılında Türkiye'de 20 yaş ve üzerindeki popülasyonda yaptığı çalışmada, yaşa göre standardize edilmiș diyabet prevalansı \%13.7'dir. ${ }^{29}$ Aynı ekibin 1997'de yaptı̆̆ çalıșmada prevalans \%7 olup, son 13 yılda \%95 oranında artmıștır. 30

Yapılan çalışmalar, her on hastanın dokuzunda, değiştirilebilir davranışlar ve yaşam biçimi nedeniyle T2D geliştiğini göstermektedir. ${ }^{16,31}$ Hastalığın ve komplikasyonlarının tedavisinde ilerleme kaydedilmesine rağmen, hastalık yükünün giderek artması, korumada yeni yaklaşımların gerekliliğini ortaya koymaktadır. ${ }^{13}$

\section{Konu ile ilgili araştırmalar:}

D vitamini son zamanlarda T2D'in etiyopatogenezi ve önlenmesinde giderek artan bir şekilde gündeme gelmektedir. Yetersizliğinin riski artırdığı belirtilmekle birlikte, bu konuda yapılmış araştırmaların çoğu kesitsel olduğu için, epidemiyolojik kanıtlar sınırlıdır.16,32 Çalışmaların bir bölümünde, diyetle alınan $\mathrm{D}$ vitamini 
dikkate alınmış olup, günlük $\mathrm{D}$ vitamini ihtiyacının \%70'ini oluşturan endojen sentez dikkate alınmamıştır. ${ }^{32} \mathrm{D}$ vitamini yetersizliği ile T2D'in obezite, fiziksel inaktivite, yaş gibi çeşitli ortak risk faktörleri bulunmakta olup, ${ }^{10}$ her ikisinin de sıklığı giderek artmaktadır. Aralarındaki potansiyel ilişki, Halk Sağlığı açısından önemlidir. Bu durum, kesitsel çalışmalar, prospektif çalışmalar ve klinik deneylerde de gösterilmiștir.12 Bununla birlikte D vitamini yetersizliği olan T2D hastalarına $\mathrm{D}$ vitamini verilmesinin yol açtığı sonuçlar çelişkili olup, bazı çalışmalarda glisemik kontrolün düzeldiği; bazılarında düzelmediği belirtilmektedir. 33

\section{Tanımlayıcı araştırmalar:}

Londra'da yaşayan Bangladeşlilerde yapılan bir çalışmada, T2D riski olanlardaki D vitamini düzeyinin, risk altında olmayanlardan fazla olduğu gösterilmiştir. ${ }^{34,35}$ Yapılan başka bir çalışmada, uzun süreli D vitamini tedavisinin, insülin salınımını arttırdığı ve glikoz düzeyini normalleştirdiği belirtilmiștir. ${ }^{36}$

D vitaminin glikoz metabolizması üzerindeki etkisi ile ilgili öngörülen mekanizmalar, insülin sentezi ve parathormon etkisi ile ortaya çıkan insülin duyarlılığı üzerindeki negatif etkiler olarak belirtilmektedir.4,37

\section{Kesitsel araștırmalar:}

Birçok kesitsel klinik çalışmada, $25(\mathrm{OH}) \mathrm{D}_{3}$ vitamini ile insülin direnci ilișkili bulunmuștur. Hatta diyabet olmayanlarda bile yaş, cinsiyet, beden kitle indeksi ve fiziksel aktivitenin etkisi kontrol edildikten sonra, düşük serum $25(\mathrm{OH}) \mathrm{D}_{3}$ düzeyinin prediyabetle ilişkili olduğu gösterilmiştir.12,38

Kesitsel çalışmalar, 25(OH) $\mathrm{D}_{3}$ düzeyinin, bozulmuş glikoz toleransı ve T2D'i olanlarda, normal glikoz toleransı olanlardan düşük olduğunu göstermiștir.12,39,40

Bulgarlarda yapılan bir çalışmada, T2D'i olan kadınlarda D vitamini yetersizliği prevalansının yüksek olduğu ve D vitamini verilmesinin, insülin salınımını ve etkinliğini normalleştirdiği belirtilmiştir. ${ }^{41}$

Chiu ve arkadaşlarının yaptığı bir çalışmaya göre, D vitamini yetersizliğinin metabolik sendrom prevalansını arttırdığı; $25(\mathrm{OH}) \mathrm{D}_{3}$ düzeyi ile insülin duyarlılığı ve beta hücre fonksiyonunun negatif yönde ilişkili olduğu; D vitamini yetersizliğinin, T2D ve metabolik sendromda görülen insülin direnci için bağımsız bir risk faktörü olduğu bildirilmiştir. ${ }^{42}$

Amerikalılar tarafından gerçekleştirilen Üçüncü Ulusal Sağlı ve Beslenme Araştırması'nda (National Health and Nutrition Examination SurveyNHANES), T2D ile ilişkili risk faktörlerinin etkisi kontrol edildiğinde, $25(\mathrm{OH}) \mathrm{D}_{3}$ düzeyinin, hastalıkla azalan yönde ilișkili olduğu ve prevalansın, D vitamini ile doz cevap ilişkisi gösterdiği belirtilmiştir.43,44

Bellan ve arkadaşları tarafından yapılan bir çalıșmada, D vitamini düzeyinin değişmesinin, T2D diyabet riskini etkilediği belirtilmiştir. $\mathrm{D}$ vitamini yetersizliği prevalansının; bozulmuş açlık glikozu, bozulmuş glikoz toleransı ve T2D'i olanlarda anlamlı düzeyde arttı̆̆ı; glikoz dengesinin düzenlenmesinde, insülin salınımı ve lipid metabolizması üzerinde bağımsız etkisinin olduğu bildirilmiştir. ${ }^{4}$

Lim ve arkadașlarının yaptığı bir çalışmada; obezite, insülin direnci ve diğer bilinen risk faktörlerinin etkisi kontrol edildikten sonra, $25(\mathrm{OH}) \mathrm{D}_{3}$ eksikliği olanlarda T2D riskinin 3.4 kat fazla olduğu bildirilmiștir. ${ }^{5}$

Tımim'in yaptığı bir çalışmada, yetersiz $\mathrm{D}$ vitamini düzeyinin, insülin duyarlılığını azalttığı bildirilmiştir. HbA1c düzeyinin de $\mathrm{D}$ vitamini düzeyiyle ilişkili olduğu ve $\mathrm{D}$ vitamini düzeyi azaldıkça, HbA1c düzeyinin arttığı belirtilmiştir. ${ }^{33}$ 
Postigo'nun yaptığı bir çalışmada, $25(\mathrm{OH}) \mathrm{D}_{3}$ vitamini düzeyinin, prediyabetik ve diyabetik grupta, normoglisemik gruba göre anlamlı olarak daha düşük olduğu; ayrıca, D vitamini reseptör gen ekspresyonunun, morbid obezlerde daha yüksek olduğu bulunmuştur. ${ }^{45}$

\section{Vaka kontrol araștırmaları:}

Avustralya'da yapılan bir çalıșmada, yeni tanı alan T2D ya da glikoz intoleransı olanlarda D vitamini düzeylerinin, eşleştirilmiş kontrollerden düşük olduğu saptanmıştır. ${ }^{46}$

Knekt ve arkadaşlarının yaptığı yuvalanmış bir vaka kontrol çalışmasında, 412 kişide T2D gelişmiş; $25 \mathrm{nmol} / \mathrm{L}$ altındaki değerlerde, riskin erkeklerde arttığı; kadınlarda anlamlı bir değișikliğin olmadı̆̆ gözlenmiștir. ${ }^{47}$ Bir başka yuvalanmıș vaka kontrol çalışmasında da prediyabet olanlar 8-10 yıl izlenmiş ve T2D riskinin arttığı saptanmıştır. 48

\section{Prospektif araştırmalar:}

Prospektif çalışmalarda, serum $25(\mathrm{OH}) \mathrm{D}_{3}$ düzeyi ile T2D insidansı arasında azalan yönde anlamlı bir ilişki olduğu gösterilmiştir. Düşük $25(\mathrm{OH}) \mathrm{D}_{3}$ düzeyi ile T2D mekanizması arasındaki ilişki net olmamakla birlikte D vitamini düzeyinin, insülin direnci ve beta hücre fonksiyonu ile ilişkili olduğu belirtilmiștir. ${ }^{49}$

Hollanda'da yapilan toplum tabanlı prospektif bir çalışmada, yaşlı erkeklerdeki D vitamini düzeyinin, glikoz toleransı ve insülin salınımı ile negatif yönde ilișkili olduğu gösterilmiștir. ${ }^{50}$

Danimarka'da 4,296 kişinin 5 yll izlendiği bir çalışmada, karıştırıcı faktörlerin etkisi kontrol edildikten sonra D vitamini yetersizliğinin T2D insidansını etkilemediği; ancak, glikoz dengesini bozduğu gösterilmiștir. ${ }^{33}$

Pittas ve arkadaşları, hafif ve orta düzeydeki $\mathrm{D}$ vitamini yetersizliğinin, T2D için risk faktörü olduğunu ${ }^{14}$ ve yüksek plazma D vitamini konsantrasyonunun, T2D riski taşıyanlarda riski azalttığını belirtmiştir. ${ }^{51}$

Avustralya'da yapılan bir çalışmada, D vitamini eksikliğinin T2D ve metabolik sendromla ilișkili olduğu saptanmıștır.9,16 Birçok prospektif çalışmada, düşük $25(\mathrm{OH}) \mathrm{D}_{3}$ düzeyinin metabolik sendrom ve diyabetle ilişskili olduğu gösterilmiştir. ${ }^{19}$

Dalgard ve arkadaşlarının yaptığı bir çalışmada, yetersiz $25(\mathrm{OH}) \mathrm{D}_{3}$ düzeyinin T2D riskini 2 kat arttırdığı belirtilmiștir. ${ }^{49}$

Kayaniyil ve arkadaşlarının yaptığ bir çalışmada, yüksek serum $25(\mathrm{OH}) \mathrm{D}_{3}$ konsantrasyonunun, beta hücre işlevini iyileştirdiği ve T2D gelişimini azalttığ gösterilmiştir. ${ }^{52}$

Elli-yetmiş dört yaş grubundaki 7,791 kișide yürütülen ve 8 yıl izlenen bir çalışmada, 829 kişide T2D gelişmiş; kadınlarda, D vitamini düzeyinin $40 \mathrm{nmol} / \mathrm{L}$ ve altında olması durumunda, T2D ile D vitamini düzeyi arasında anlamlı ve azalan yönde doz-cevap ilişkisi olduğu gözlenmiştir. Bu ilişki, D vitamini düzeyinin 70 nmol/L'ün altına düşmesi ile belirginleşmiş; erkeklerde anlamlı bir ilişki gözlenmemiştir. ${ }^{53}$

Hollanda'da 9,841 kişinin 29 yl izlendiği bir çalışmada, D vitamini düzeyinin $\geq 20 \mathrm{mikrogram} / \mathrm{L}$ ( $\geq 50 \mathrm{nmol} / \mathrm{L}$ ) olmasının yeterli; $\quad 10-19.9$ mikrogram/L (25-49.9 nmol/L) olmasının eksiklik; 5-9.9 mikrogram/L (12.5-24.9 nmol/L) olmasının yetersizlik ve $<5$ mikrogram/L $\quad(<12.5$ nmol/L) altında olmasinın ileri derecede yetersizlik olarak değerlendirilmiş ve 810 kişide T2D gelişmiştir. Beden kitle indeksindeki artışın, 25(OH)D $\mathrm{D}_{3}$ düzeyi ile azalan yönde ilișkili olduğu; $25(\mathrm{OH}) \mathrm{D}_{3}$ düzeyi arttıkça, T2D insidansının azaldığı gösterilmiştir. ${ }^{54}$

\section{Meta analiz çalışmaları:}

Yapılan bazı meta analiz ve sistematik derleme çalışmalarında, D 
vitamini eksikliği ile glikoz intoleransının ilişkili olduğu gösterilmiştir.9,16 Ancak, on beş çalışmanın incelendiği bir çalışmada, D vitamini verilmesinin ne T2D gelişimini önlediği ne de glisemik kontrolü düzelttiği belirtilmiștir. ${ }^{19}$

On sekiz prospektif çalışmadan elde edilen on yedi makaleyi kapsayan bir meta analiz çalışmasına göre, D vitamini düzeyi ile T2D riski negatif ilişkili bulunmuştur. ${ }^{1}$

Epidemiyolojik çalıșmalar, D vitamini düzeyi ile T2D riski arasında azalan yönde bir ilişki olduğunu göstermekte olup,16,55,56 3,600 kişinin izlendiği EPICNorfolk çalışmasında yer alan on bir prospektif çalışmanın meta analiz sonuçlarına göre, serum $25(\mathrm{OH}) \mathrm{D}_{3}$ ile T2D insidansı arasında azalan bir ilişki olduğ $\mathrm{u}^{13,55}$ ve $\mathrm{D}$ vitamini verilmesi ile T2D riskinin \%41 oranında azaldığı belirtilmiştir (\%95 GA: \%33- \%48). 55

Sekiz çalışmanın değerlendirildiği bir çalışmada, glikoz intoleransı olanlara D vitamini verilmesinin, açlık plazma glikoz düzeyini anlamlı ölçüde (\%95 GA: 0.060.09) azalttığı saptanmıștır. ${ }^{19}$

Danimarka'da yapılan toplum tabanlı prospektif bir çalışmanın ve daha önce yayımlanmış tüm prospektif çalışmaların da incelendiği bir çalışmada, 810 kişide T2D geliștiği; D vitamini yetersizliği olanlardaki T2D riskinin, olmayanlardan 1.5 kat fazla olduğu belirtilmiștir. ${ }^{44}$

\section{Öneriler:}

Küresel ölçekte artmakta olan diyabetin önlenmesiyle ilgili yaklaşımlar oldukça geniş kapsamlıdır. Kiloluluk, obezite fiziksel inaktivite ve sağlıksız beslenme gibi önlenebilir risk faktörlerinin prevalansının azaltılması için çok sektörlü, toplum-tabanlı yaklaşımlara gereksinim bulunmaktadır. ${ }^{26}$ T2D'in birincil korumasında yüksek riskli bireylerde yaşam biçimi ve davranışlarının değiştirilmesi umut vadeden bir stratejidir. Buna ek olarak gruplarda $25(\mathrm{OH}) \mathrm{D}_{3}$ düzeyinin belirlenmesi; hastalığın önlenmesi ve tedavisinde değerlendirilebilecek yaklaşımlardan biri olabilir. ${ }^{33}$

D vitaminin; insülin salınımı, insülin duyarlılı̆̆ etkileyeceği ile ilgili kesitsel ve prospektif çalışmalar, vitaminin T2D'in gelişimini önlediğini genel olarak desteklemektedir. ${ }^{10}$ D vitamini yetersizliği ve bunun sağlık üzerindeki potansiyel etkileri önemli olup, diyabet yükünün fazla olduğu pek çok ülkede $25(\mathrm{OH}) \mathrm{D}_{3}$ düzeyi önerilen sınırların altındadır. ${ }^{57,58}$

T2D ile D vitamini yetersizliği arasındaki potansiyel ilişkinin mekanizması net değildir. D vitamini düzeyi; beta hücre işlevi, insülinin salınımı ve sistemik enfeksiyonu etkileyebilir. Veriler, D vitamininin T2D'in önlenmesi ve tedavisinde yararlı olabileceğini göstermektedir.59 Yapılan çalışmalar, $25(\mathrm{OH}) \mathrm{D}_{3}$ 'ün T2D riskini azaltmasıyla ilgili olumlu kanitlar sunmakla birlikte, konunun daha fazla araştırılması gerekmektedir..$^{55}$

Alanda yapılan preklinik ve gözlemsel çalışmalardan elde edilen kanitlar, D vitaminin T2D riskinin belirlenmesinde umut veren bir marker olduğunu göstermekle birlikte, bu ilişkiyi karıștıran ve vitaminin biyoyararlılığını azaltan obezite gibi faktörler bulunmaktadır. Müdahale araştırmaları ile netleştirilmesi gereken soru, D vitamininin, diyabetin tedavisinde $\mathrm{mi}$, yoksa önlenmesinde mi etkili olduğu; diğer bir soru da diyabet riski taşıyan ya da diyabet olanlara verilmesi gereken D vitamini dozu ve süresidir. $D$ vitamini yetersizliği ve T2D prevalansının her ikisinin birlikte artması, aralarındaki olası potansiyel ilişkinin belirlenmesi, Halk Sağlığı açısından önemlidir. ${ }^{12} \mathrm{Bu}$ yüzden nedenselliğin ortaya konması; T2D'in önlenmesi ve tedavisi için, glikoz intoleransı bulunan yüksek risk altındaki bireylerde $\mathrm{D}$ vitamini ve T2D ilişkisinin netleștirilmesi, hangi durumda ne dozda ve ne kadar süre ile $\mathrm{D}$ vitamini verilmesi gerektiği ortaya konmalı ve bunun 
için de kapsamlı randomize kontrollü klinik çalışmalar yapılmalıdır.1,9,13,16,33,55

\section{Kaynaklar}

1. Khan $\mathrm{H}$, Kunutsor $\mathrm{S}$, Franco $\mathrm{OH}$, Chowdhury R. Vitamin D, Type 2 Diabetes and other metabolic outcomes: a systematic review and meta-analysis of prospective studies. Proceed Nutr Soc 2013; 72(1):8997.

2. Holick MF. Resurrection of vitamin D deficiency and rickets. J Clin Invest 2006;116(8):2062-2072.

3. Holick MF, Garabedian M. Vitamin D: photobiology, metabolism, mechanism of action, and clinical applications. In: Favus MJ, ed. Primer on the metabolic bone diseases and disorders of the mineral metabolism. 6th ed. American Society for Bone and Mineral Research, Washington 2006, pp. 129-137.

4. Bellan M, Guzalloni G, Rinaldi $\mathrm{M}$ et al. Altered glucose metabolsim rather than naive type 2 diabetes mellitus (T2D) is related to vitamin D status in severe obesity. Card Diabetol 2014;13(57):1-10.

5. Lim S, Kim MJ, Choi CS et al. Association of vitamin D deficiency with incidence of type 2 diabetes in high-risk Asian subjects. Am J Clin Nutr 2013;97(3):524-530.

6. Rosen CJ, Adams JS, Bikle DD et al. The nonskeletal effects of vitamin D: An endocrine society scientific statement. Endocr Rev 2012;33(3):456-492.

7. Lim S, Shin H, Kim MJ et al. Vitamin D in adequacy is associated with significant coronary artery stenosis in a communitybased elderly cohort: the Korean Longitudinal Study on Health and Aging. J Clin Endocrinol Metab 2012;97(1):169-178.

8. Palomer X, Gonzales-Clemente JM, Blanco Vaca F, Mauricio D. Role of Vitamin D in the pathogenezis of type 2 diabetes mellitus. Diab Obes Metab 2008;10(3):185-197.
9. Mezza T, Muscogiuri Sorice GP, Prioletta A et al. Vitamin D Deficiency: A New Risk Factor For Type 2 Diabetes? Ann Nutr Met 2012;61(4):337-348.

10. Alvarez JA, Ashraf A. Role of Vitamin D in Insulin Secretion and Insulin Sensitivity for Glucose Homeostasis. Int J Endocrinol 2010(2010); p 1-18.

11. Lee BK, Park S, Kim Y. Age- and genderspecific associations between low serum 25hydroxyvitamin $\mathrm{D}$ level and type 2 diabetes in the Korean general population: analysis of 2008-2009; Korean National Health and Nutrition Examination Survey data. Asia Pac J Clin Nutr 2012;21(4):536-546.

12. Stivelman E, Retnakaran R. Role of Vitamin D in the Pathophysiology and Treatment of Type 2 Diabetes. Curr Diab Rev 2012;8(1):42-47.

13. Mitri J, Muraru MD, Pittas AG. Vitamin D and type 2 diabetes: A Systematic Review. Eur J Clin Nutr 2011;65(9):1005-1015

14. Cangoz S, Chang Y-Y, Chempakaseril SJ et al. Vitamin D and type 2 diabetes mellitus. J Clin Pharm Therap 2013;38(2):81-84.

15. Gedik 0, Akalın S. Effects of Vitamin D deficiency and repletion on insülin and glucagon secretion in man. Diabetologia 1986;29(2):142-145.

16. Pittas AG, Lau J, Hu F, Dawson-Hughes B. The role of Vitamin $D$ and Calcium in type 2 diabetes. A systematic Review and MetaAnalysis. J Clin Endocrinol Metab 2007;92(6):2017-2029.

17. Adams JS, Hewison M. Update in vitamin D. J Clin Endocrinol Metab 2010;95(2):471478.

18. Holick MF. Vitamin D deficiency. New Engl J Med 2007;357(3):266-281.

19. George PS, Pearson ER, Witham MD. Effect of vitamin D supplementation on glycaemic control and insülin resistance: a systematic review and meta- analysis. Diab Med 2012;29(8):e142-e150.

20. Segal S, Lloyd S, Sherman N, Sussman K, Draznin B. Postprandial changes in cytosolic 
free calcium and glucose uptake in adipocytes in obesity and non-insulin dependent diabetes mellitus. Horm Res 1990;34:39-44.

21. Ohno Y, Suzuki H, Yamakawa H, Nakamura M, Otsuka K, Saruta T. Impaired insulin sensitivity in young, lean normotensive offspring of essential hypertensives: possible role of disturbed calcium metabolism. J Hypertens 1993;11(4):421-426.

22. Zemel MB. Nutritional and endocrine modulation of intracellular calcium: implications in obesity, insülin resistance and hypertension. Mol Cell Biochem 1998;188(1-2):129-136.

23. Holick MF, Chen TC. Vitamin D deficiency: A worldwide problem with health consequences. Am J Clin Nutr 2008;87(suppl):1080S-1086S.

24. Grineva EN, Karonova T, Micheeva E, Belyaeva 0 , Nikitina IL. Aging 2013;5(7):575-581.

25. American Diabetes Association. Report of the Expert Commitee on the Diagnosis and Classification of Diabetes Mellitus: follow-up report on the diagnosis of diabetes mellitus. Diabetes Care 2003;26(11):3160-3167.

26. Global Report on Diabetes 2016. Erişim adresi:

http://www.who.int/diabetes/globalreport/en/ Erişim tarihi:22.10.2016.

27. Global status report on noncommunicable diseases. Erişim adresi: http://www.who.int/nmh/publications/ncstatus-report-2014/en/ Erișim tarihi: 25.02.2016.

28. World Health Organization. Definition, diagnosis and classification of diabetes mellitus and its complications. Part 1: Diagnosis and classification of diabetes mellitus. Geneva, World Health Organization, 1999 (WHO/NCD/NCS/99.2).

29. Satman I, Ömer B, Tütüncü $Y$ et al. Twelve Year Trends in the Prevalance and risk factors of Diabetes and prediabetes in Turkish adulta. Eur J Epidemiology 2013:28(1):169-180.

30. Satman I, Yllmaz T, Sengul A et al. The TURDEP Group: Population based study of diabetes and risk characteristics in Turkey: results of the Turkish diabetes epidemiology study (TURDEP). Diabetes Care 2002;25(9):1551-1556.

31. Evaluation, Treatment, and Prevention of Vitamin D Deficiency: An Endocrine Society Clinical Practice Guideline. The Endocrine Society's Clinical Guidelines. (C) The Endocrine Society, 2011.

32. Husemoen LLN, Thuesen BH, Fenger M et al. Serum 25(OH)D and Type 2 Diabetes Association in a General population. A prospective study. Diabetes Care 2012;35(8):1695-1700.

33. Al Tımim DJ, Ardawan FA. Serum 25(OH) D in Diabetes Mellitus Type 2: Relation to Glycaemic Control. J Clin Diag Research 2013;7(12):2686-2688.

34. Boucher BJ, Mannan N, Noonan $\mathrm{K}$ et al. Glucose intolerance and impairment of insülin secretion in relation to vitamin $\mathrm{D}$ deficiency in East London Asians. Diabetologia 1995;38(10):1239-1245.

35. Zittermann A. Vitamin D in preventive medicine: are we ignoring the evidence? $\mathrm{Br} J$ Nutr 2003; 89(5):552-572.

36. Boucher BJ. Inadequate vitamin D status: does it contribute to the disorders comprising syndrome ' $\mathrm{X}$ '. Br J Nutr 1998;79(4):315-327.

37. Alvarez JA, Ashraf AP, Hunter GR, Gower BA. Serum 25-hydroxyvitamin D and parathyroid hormone are independent determinants of whole-body insulin sensitivity in women and may contribute to lower insulin sensitivity in African Americans. Am J Clin Nutr 2010;92(6):13441349.

38. Scragg R, Sowers M, Bell C. Third National Health and Nutrition Examination Survey. Serum 25 hydroxyvitamin D, 
Diabetes and Ethnicity in the third National Health and Nutrition Examination Survey. Diabetes Care 2004;27(12):2813-2818.

39. Isaia G, Giorgino R, Adami S. High prevalance of hypovitaminosis $\mathrm{D}$ in female type 2 diabetic population. Diabetes Care 2001;24(8):1496.

40. Targher G, Bertollini L, Padovani et al. Serum 25-hydroxyvitamin $\quad \mathrm{D}_{3}$ concentrations and carotid artery intimamedia thickness among type 2 diabetic patients. Clin Endocrinol (Oxf) 2006;65(5):593-597.

41. Borissova AM, Tankova T, Kirilov G et al. The effect of vitamin $\mathrm{D}_{3}$ on insülin secretion and peripheral insülin sensitivity in type 2 diabetic patients. Int J Clin Pract 2003;57: 258-261.

42. Chiu KC, Chuang LM, Yoon C. The vitamin $\mathrm{D}$ receptor polymorphism in the translation initiation codon is a risk factor for insulin resistance in glucose tolerant Caucasians. BMC Med Genet 2001;2(2):1-8.

43. Scragg R, Sowers M, Bell C. Serum 25 hydroxyvitamin $\mathrm{D}$, diabetes and ethnicity in the third National Health and Nutrition Examination Survey. Diabetes Care 2004;27(12):2813-2818.

44. Mitri J, Muraru MD, Pittas AG. Vitamin D and type 2 diabetes: a systematic review. Eur J Clin Nutr 2011;65(9):1005-1015.

45. Araceli Muñoz-Garach, Mercedes Clemente-Postigo, Diego Fernandez-García, Fernando Cardona-Diaz, Manuel MaciasGonzalez \& Francisco Tinahones-Madueño. Relationship between serum 25hydroxivitamin D3 and adipose tissue vitamin D receptor gene expression with obesity and type 2 diabetes. Endocrine Abstracts (2015) DOI: http://dx.doi.org/10.1210/jc.2014-3016

46. Scragg R, Holdaway I, Singh V et al. Serum 25-hydroxyvitamin $\mathrm{D}_{3}$ levels decreased in IGT and diabetes. Diabetes Res Clin Pract 1995;27(3):181-188.
47. Knekt $\mathrm{P}$, Laaksonen $\mathrm{M}$, Mattila $\mathrm{C}$ et al. Serum vitamin $\mathrm{D}$ and subsequent occurrence of type 2 diabetes. Epidemiology 2008;19(5):666-671.

48. Deleskog A, Hilding A, Brismar K, Hamsten A, Efendic S, Östenson CG. Low serum 25-hydroxyvitamin D level predicts progression to type 2 diabetes in individuals with prediabetes but not with normal glucose tolerance. Diabetologia 2012;55(6):1668-1678.

49. Dalgard C, Skaalum Peterson M, Weihe P, Grandjean P. Vitamin D status in relation to glucose metabolism in septuagenarians. Diabetes Care 2011;34(6):1284-1288

50. Baynes KCR, Boucher BJ, Feskens EJM et al. Vitamin D, glucose tolerance and insulinaemia in elderly men. Diabetologia 1997;40(3):344-347.

51. Pittas A, Nelson J, Mitri J, Hilmann W, Garganta C, Nathan D et al. Plasma 25hydroxy vitamin $\mathrm{D}$ and progression to diabetes in patients at risk for diabetes: an ancillary analysis in the Diabetes Prevention Programme. Diabetes Care 2012;35(3):565573.

52. Kayaniyil S, Retnakaran R, Haris SB et al. Prospective associations of vitamin $\mathrm{D}$ with beta-cell function and glycemia: the PROspective Metabolism and ISlet cell evaluation (PROMISE) cohort study. Diabetes 2011;60(11):2947-2953.

53. Schöttker B, Herder C, Rothenbacher D, Perna L, Müler H, Brenner H. Serum 25hydroxyvitamin D levels and incident diabetes mellitus type 2: a competing risk analysis in a large population-based cohort of older adults. Eur J Epidemiol 2013;28(3):267-275.

54. Afzal S, Bojesen SE, Nordestgaard BG. Low 25-Hydroxyvitamin D and Risk of Type 2 Diabetes: A prospective Cohort Study and Metaanalysis. Clin Chem 2013;59(2):381391.

55. Forouhi NG, Rickard Z Ye AP, Khaw KT, Luben R, Langenberg C, Wareham NJ. Circulating 25-hydroxyvitamin D 
concentration and the risk of type 2 diabetes: results from the european Prospective Investigation into Cancer (EPIC)-Norfolk cohort and updated metaanalysis of prospective studies. Diabetologia 2012;55(8):2173-2182.

56. Pittas AG, Sun Q, Manson JE, DawsonHughes $\mathrm{B}, \mathrm{Hu}$ FB. Plasma 25hydroxyvitamin $\mathrm{D}$ concentration and risk of incident type 2 diabetes in women. Diabetes Care 2010;33(9):2021-2023.

57. Giovannucci E.Can vitamin D reduce total mortality? Arch Intern Med 2007;167(16):1709-1710.

58. van Schoor NM, Lips P. Worldwide vitamin D status. Best Pract Res Clin Endocrinol Metab 2011;25(4):671-80.

59. Mathieu C, Gysemans C, Giulietti A, Bouillon R. Vitamin D and diabetes. Diabetologia 2005;48(7):1247-1257. 